\title{
Meningkatkan Hasil Belajar Siswa Pada Operasi Penjumlahan Bilangan Bulat Dengan Menggunakan Model Pembelajaran Numbered Head Together
}

\author{
Fitria Puspitasari ${ }^{1}$, Yusuf Suryana ${ }^{2}$, Geri Syahril Sidik ${ }^{3}$ \\ 1,3 Universitas Perjuangan Tasikmalaya, ${ }^{2}$ Universitas Pendidikan Indonesia \\ fitriapuspita77@gmail.com
}

\section{Article History}

accepted 2/11/2019

approved 23/11/2019

published 31/12/2019

\begin{abstract}
This research is motivated by the low student learning outcomes in integer addition operation material in Class IV SDN Sindangheula. The purpose of this study is to improve student learning outcomes in integer addition operations using the Numbered Head Together (NHT) learning model. The method used in this study is the Classroom Action Research (CAR) method. The results showed that the learning process was not optimal before the use of the NHT learning model. This is seen from the results of the pre-test of student learning completeness only reached $29 \%$ with an average score of 53.33. Cycle I and cycle II showed an increase in student learning outcomes. Data obtained from student learning outcomes in the first cycle reached $67 \%$ with an average score of 72.38 . Cycle II reaches $95 \%$ with an average score of 90.48. An increase in the average score of student learning outcomes reached 18.1 points. Based on the increasing data from each cycle, mathematics learning using the NHT model can improve student learning outcomes in integer addition operations in Class IV SDN Sindangheula, Cibalong District, Tasikmalaya District, Academic Year 2018/2019.
\end{abstract}

Keywords: Learning Outcomes, NHT Learning Model

\begin{abstract}
Abstrak
Penelitian ini dilatarbelakangi oleh rendahnya hasil belajar siswa pada materi operasi penjumlahan bilangan bulat di Kelas IV SDN Sindangheula. Tujuan penelitian ini untuk meningkatkan hasil belajar siswa pada operasi penjumlahan bilangan bulat dengan menggunakan model pembelajaran Numbered Head Together (NHT). Metode yang digunakan dalam penelitian ini yaitu metode Penelitian Tindakan Kelas (PTK). Penelitian ini dilaksanakan dalam dua siklus. Setiap siklus terdiri dari tahapan: 1) peneliti memberikan soal pre test; 2) peneliti melaksanakan tindakan model pembelajaran NHT; 3) siswa diberikan soal post test; 4) peneliti merefleksi kegiatan penelitian untuk perbaikan siklus selanjutnya. Hasil penelitian menunjukkan bahwa hasil pre test ketuntasan belajar siswa hanya mencapai $29 \%$ dengan ratarata skor 53,33. Siklus I dan siklus II memperlihatkan adanya peningkatan hasil belajar siswa. Data yang diperoleh dari hasil belajar siswa pada siklus I mencapai $67 \%$ dengan rata-rata skor 72,38. Siklus II mencapai 95\% dengan rata-rata skor 90,48. Peningkatan rata-rata skor hasil belajar siswa mencapai 18,1 poin. Berdasarkan data peningkatan dari setiap siklus, pembelajaran matematika dengan menggunakan model $\mathrm{NHT}$ dapat meningkatkan hasil belajar siswa pada operasi penjumlahan bilangan bulat di Kelas IV SDN Sindangheula Kecamatan Cibalong Kabupaten Tasikmalaya Tahun Ajaran 2018/2019.
\end{abstract}

Kata Kunci: Hasil Belajar, Model Pembelajaran NHT

Social, Humanities, and Education Studies (SHEs): Conference Series https://jurnal.uns.ac.id/shes

p-ISSN 2620-9284

e-ISSN 2620-9292 


\section{PENDAHULUAN}

Salah satu kompetensi dasar yang termuat dalam Kurikulum Tingkat Satuan Pendidikan (KTSP) pada mata pelajaran matematika Kelas IV Semester II yaitu tentang operasi penjumlahan bilangan bulat. Menurut Herman, T. dkk. (2010) "Bilangan bulat adalah gabungan antara bilangan asli, dengan bilangan-bilangan negatifnya serta bilangan 0 ." Materi penjumlahan bilangan bulat wajib dikuasai oleh siswa, karena materi ini merupakan penunjang materi-materi selanjutnya.

Berdasarkan studi pendahuluan melalui wawancara dengan guru kelas IV SDN Sindangheula, bahwa hasil belajar siswa dalam materi penjumlahan bilangan bulat masih rendah. Hal ini disampaikan oleh guru kelas bahwa hasil tes evaluasi belajar siswa pada materi bilangan bulat masih kurang memuaskan dengan Kriteria Ketuntasan Minimal (KKM) yang telah ditetapkan yaitu 68. Dari 21 orang siswa yang dinyatakan tuntas hanya 7 orang, dengan persentase sebesar $33 \%$, dan yang belum tuntas sebanyak 14 orang mendapatkan skor rata-rata di bawah KKM \pm 55 dengan persentase sebesar $67 \%$. Persentase ketuntasan siswa masih jauh dari harapan. Hal tersebut menurut Sidik (2019) diakibatkan karena siswa banyak mengalami kesulitan pada saat memahami maksud soal sehingga salah menerjemahkan ke kalimat matematika dan mengoperasikan bilangan yang memuat tanda negatif. Mujiani (2016), Haryati, N. (2015), dan Alfiyah, S (2012) faktor penyebab rendahnya hasil belajar siswa yaitu, "proses pembelajaran kurang menggunakan media, kurangnya minat dalam mengikuti pembelajaran, siswa kesulitan dalam belajar, kurangnya model pembelajaran yang digunakan sehingga hasil belajar siswa rendah." Model pembelajaran yang digunakan berpengaruh terhadap hasil belajar siswa. Menurut Dewi, F. (2016) "model pembelajaran yang digunakan dalam proses pembelajaran sangat mempengaruhi hasil belajar yang ingin dicapai siswa."

Berdasarkan hasil observasi, banyak hal yang sudah dilakukan oleh guru untuk memperbaiki hasil belajar siswa yaitu 1) dengan memberikan latihan soal-soal yang sama atau remedial, Hasibuan, N. (2014) menyatakan bahwa "Pembelajaran remedial merupakan layanan pendidikan yang diberikan kepada peserta didik untuk memperbaiki prestasi belajarnya sehingga mencapai kriteria ketuntasan yang ditetapkan." maka pemberian remedial hanya berupa soal-soal saja belum efektif, 2) siswa dikelompokkan dalam kegiatan pembelajaran tetapi siswa belum terlibat aktif dalam proses pembelajaran. Proses belajar siswa bersifat individual dalam mengerjakan soal-soal, sehingga kurangnya keterlibatan siswa dalam pembelajaran kooperatif. Rusman (2016) mengemukakan bahwa "Pembelajaran kooperatif merupakan bentuk pembelajaran dengan cara siswa belajar dan bekerja dalam kelompok-kelompok kecil secara kolaboratif yang anggotanya terdiri dari empat sampai enam orang dengan struktur kelompok yang bersifat heterogen." Siswa belum terlibat aktif dalam kegiatan kelompok, hal ini mengakibatkan hasil belajar siswa pada operasi penjumlahan bilangan bulat masih rendah.

Salah satu model pembelajaran yang digunakan oleh peneliti pada pembelajaran operasi penjumlahan bilangan bulat adalah model pembelajaran NHT. Trianto (2010) menyatakan bahwa "NHT atau penomoran berpikir bersama merupakan jenis pembelajaran kooperatif yang dirancang untuk mempengaruhi pola interaksi siswa dan sebagai alternatif terhadap struktur kelas tradisional." Model pembelajaran NHT dapat memberikan kesempatan pada siswa untuk saling membagikan ide-ide dan mempertimbangkan jawaban yang paling tepat. Model NHT juga mendorong siswa untuk meningkatkan semangat kerjasama mereka dalam kelompok, dan meningkatkan prestasi akademik siswa dalam pembelajaran. Maryam (2015) menyatakan bahwa "penerapan model pembelajaran kooperatif tipe NHT dalam pembelajaran matematika dapat meningkatkan hasil belajar siswa." 
Berdasarkan latar belakang tersebut, peneliti tertarik melakukan penelitian untuk Meningkatkan Hasil Belajar Siswa pada Operasi Penjumlahan Bilangan Bulat dengan Menggunakan Model Pembelajaran Numbered Head Together di Kelas IV SDN Sindangheula Kecamatan Cibalong Kabupaten Tasikmalaya Tahun Ajaran 2018/2019. Tujuan penelitian ini, yaitu 1) untuk mendeskripsikan perencanaan pembelajaran dengan menggunakan model pembelajaran NHT untuk meningkatkan hasil belajar siswa pada operasi penjumlahan bilangan bulat di kelas IV, 2) untuk mendeskripsikan proses pelaksanaan pembelajaran dengan menggunakan model pembelajaran NHT untuk meningkatkan hasil belajar siswa pada operasi penjumlahan bilangan bulat di kelas IV, 3) untuk mendeskripsikan peningkatan hasil belajar siswa pada operasi penjumlahan bilangan bulat di kelas IV SDN Sindangheula dengan menggunakan model pembelajaran NHT.

\section{METODE}

Metode yang digunakan dalam penelitian ini adalah metode Penelitian Tindakan Kelas (PTK). Penggunaan metode PTK diharapkan mampu memperbaiki masalah yang terdapat di lapangan mengenai rendahnya hasil belajar siswa pada materi operasi penjumlahan bilangan bulat di Kelas IV SDN Sindangheula. Tahapan penelitian yang dilakukan oleh peneliti adalah sebagai berikut:

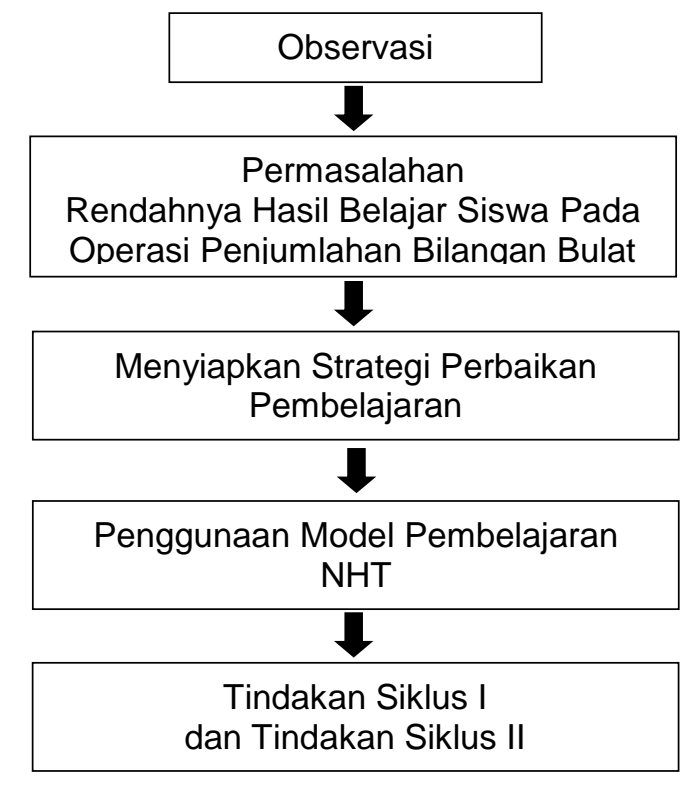

Gambar 1. Tahap Penelitian

Penelitian ini dilaksanakan di Kelas IV SDN Sindangheula Kecamatan Cibalong Kabupaten Tasikmalaya Tahun Ajaran 2018/2019. Subjek penelitian yaitu seluruh siswa kelas IV yang berjumlah 21 orang siswa, terdiri dari 8 siswa laki-laki dan 13 siswa perempuan. Peneliti melakukan observasi langsung pada siswa kelas IV untuk melihat proses pembelajaran matematika, dan menemukan permasalahan yaitu rendahnya hasil belajar siswa pada materi operasi penjumlahan bilangan bulat. Peneliti menyiapkan strategi perbaikan pembelajaran dengan menggunakan model pembelajaran NHT. Media yang digunakan dalam proses pembelajaran operasi penjumlahan bilangan bulat yaitu media kartu positif dan kartu negatif. Peneliti memberikan soal pre test sebelum pelaksanaan tindakan menggunakan model NHT, 
untuk mengetahui kemampuan awal siswa pada materi operasi penjumlahan bilangan bulat. Pembelajaran matematika pada operasi penjumlahan bilangan bulat dengan menggunakan model pembelajaran $\mathrm{NHT}$ melalui 4 fase, yaitu: 1) penomoran, peneliti membagi siswa ke dalam 4 kelompok dan setiap anggota diberi ikat kepala bernomor 1 5; 2) pengajuan pertanyaan, siswa menyimak dan menjawab pertanyaan; 3) siswa berpikir bersama dengan kelompoknya dan setiap anggota kelompok mengetahui jawabannya; 4) pemberian jawaban, siswa dari masing-masing kelompok yang nomornya disebut mengangkat tangan dan menjawab pertanyaan untuk seluruh kelas. Teknik pengumpulan data dalam penelitian ini yaitu menggunakan tes, observasi dan dokumentasi. Tes yang digunakan dalam teknik pengumpulan data ini adalah tes tertulis untuk mengukur hasil belajar siswa pada materi operasi penjumlahan bilangan bulat, berupa tes isian berjumlah 10 butir soal. Lembar observasi yang digunakan dalam penelitian ini adalah lembar observasi aktivitas peneliti, lembar observasi aktivitas siswa dan penilaian kesesuaian atau ketepatan RPP. Adapun dokumentasi yang digunakan dalam penelitian ini adalah RPP, penilaian hasil observasi, skor-skor siswa setelah pembelajaran dilaksanakan, dan foto-foto selama proses pembelajaran.

Pelaksanaan penelitian meliputi 2 siklus. Siklus I dilaksanakan pada hari Senin 29 April 2019, dan Siklus II dilaksanakan pada hari Kamis 9 Mei 2019. Tahap awal penelitian, peneliti menyiapkan semua instrumen, meliputi RPP, LKS, instrumen tes, instrumen observasi, sarana, media pembelajaran dan semua yang diperlukan dalam penelitian tindakan. Peneliti melakukan tindakan perbaikan pembelajaran dengan melaksanakan tindakan sesuai skenario pembelajaran yang tercantum dalam RPP menggunakan model pembelajaran NHT. Proses pembelajaran diamati dan dinilai oleh observer menggunakan lembar observasi. Peneliti melaksanakan pengumpulan data sesuai dengan instrumen yang direncanakan. Tahap akhir, peneliti memberikan soal post test untuk mengetahui peningkatan hasil belajar siswa pada operasi penjumlahan bilangan bulat, kemudian peneliti merefleksi kegiatan penelitian untuk perbaikan siklus selanjutnya. Data yang diperoleh berdasarkan hasil observasi dan hasil belajar siswa, kemudian diolah dan dianalisis menggunakan teknik penghitungan menurut para ahli. Data hasil analisis kemudian dipaparkan dalam bentuk tabel frekuensi dan grafik, kemudian ditarik kesimpulan berdasarkan kriteria keberhasilan yang ditetapkan. Peneliti melakukan verifikasi untuk melakukan tindakan perbaikan selanjutnya. Proses verifikasi dalam hal ini adalah memperbaiki pembelajaran dengan menafsirkan dan membuat kesimpulan tindakan-tindakan yang akan dilakukan. Penarikan kesimpulan dalam penelitian ini yaitu berdasarkan keberhasilan yang telah tercapai sampai tindakan II. 
4th National Seminar on Guidance and Counseling (SNBK 2019) and Workshop on

Pedagogical Theory and Practice (WTPP 2019)

SHEs: Conference Series 2 (2) (2019) $116-125$

HASIL DAN PEMBAHASAN

\section{Hasil Penelitian}

1. Perencanaan Pembelajaran

Hasil observasi dalam pemenuhan aspek-aspek rencana pelaksanaan pembelajaran pada pembelajaran siklus I dan siklus II dapat dirinci pada tabel 1 . sebagai berikut:

Tabel 1. Hasil Observasi RPP

\begin{tabular}{|c|c|c|}
\hline Siklus & Rata-Rata & Persentase (\%) \\
\hline I & 3,46 & $86,60 \%$ \\
\hline II & 3,85 & $96,42 \%$ \\
\hline
\end{tabular}

Melihat data hasil observasi pada tabel 1, hasil pengamatan terhadap RPP pada materi operasi penjumlahan bilangan bulat dengan menggunakan model pembelajaran NHT pada siklus I, menunjukkan hasil yang "Baik". Tetapi, indikator alokasi waktu dan pelaksanaan evaluasi belum dirancang secara proporsional karena dalam pelaksanaan evaluasi, peneliti kelebihan waktu sekitar 10 menit dari yang telah ditetapkan. Siklus II menunjukkan hasil yang "Sangat Baik".

2. Pelaksanaan Pembelajaran

Hasil observasi pelaksanaan pembelajaran dapat dirinci pada tabel sebagai berikut:

Tabel 2. Hasil Observasi Kinerja Guru

\begin{tabular}{|c|c|c|}
\hline Siklus & Rata-Rata & Persentase (\%) \\
\hline I & 3,53 & $88,39 \%$ \\
\hline II & 3,89 & $97,32 \%$ \\
\hline
\end{tabular}

Berdasarkan tabel 2, kemampuan peneliti dalam mengelola proses pelaksanaan pembelajaran pada materi operasi penjumlahan bilangan bulat menggunakan model pembelajaran NHT pada siklus I dikatakan "Baik". Indikator kemampuan guru dalam mengadakan evaluasi, peneliti kelebihan waktu sekitar 10 menit. Siklus II dikatakan "Sangat Baik".

Adapun hasil pengamatan aktivitas siswa terinci pada tabel sebagai berikut:

Tabel 3. Hasil Observasi Aktivitas Siswa

\begin{tabular}{|c|c|c|}
\hline Siklus & Rata-Rata & Persentase (\%) \\
\hline I & 3,1 & $77,5 \%$ \\
\hline II & 3,8 & $95 \%$ \\
\hline
\end{tabular}

Hasil observasi aktivitas siswa dalam proses pembelajaran pada materi operasi penjumlahan bilangan bulat, dengan menggunakan model pembelajaran NHT pada siklus I termasuk kategori "Cukup". Siswa kurang menyimak presentasi yang dilakukan oleh temannya di depan kelas dan siswa masih sulit mengajukan pendapat atau memberikan komentar terhadap presentasi kelompok yang dilaksanakan pada proses pembelajaran. Siklus II termasuk kategori "Sangat Baik". 
4th National Seminar on Guidance and Counseling (SNBK 2019) and Workshop on

Pedagogical Theory and Practice (WTPP 2019)

SHEs: Conference Series 2 (2) (2019) $116-125$

3. Hasil Belajar Siswa

Berdasarkan hasil analisis soal-soal yang diberikan, diperoleh data hasil post test pada pembelajaran pada tabel 4 sebagai berikut:

Tabel 4. Hasil Belajar Siswa

\begin{tabular}{|c|c|c|}
\hline Siklus & Rata-Rata & Persentase (\%) \\
\hline I & 72,38 & $67 \%$ \\
\hline II & 90,48 & $95 \%$ \\
\hline
\end{tabular}

Berdasarkan hasil post test pada siklus I dengan menggunakan model pembelajaran NHT dapat disimpulkan bahwa hasil belajar siswa dikatakan masih "Kurang" persenstase yang diperoleh yaitu 67\% masih kurang dari ketuntasan belajar secara klasikal (70\%). Siklus II hasil belajar siswa dikatakan "Sangat Baik" persentase yang diperoleh mencapai $95 \%$.

Data peningkatan hasil belajar siswa dengan menggunakan model pembelajaran NHT pada pembelajaran siklus 1 dan II, dapat dilihat pada grafik berikut ini:

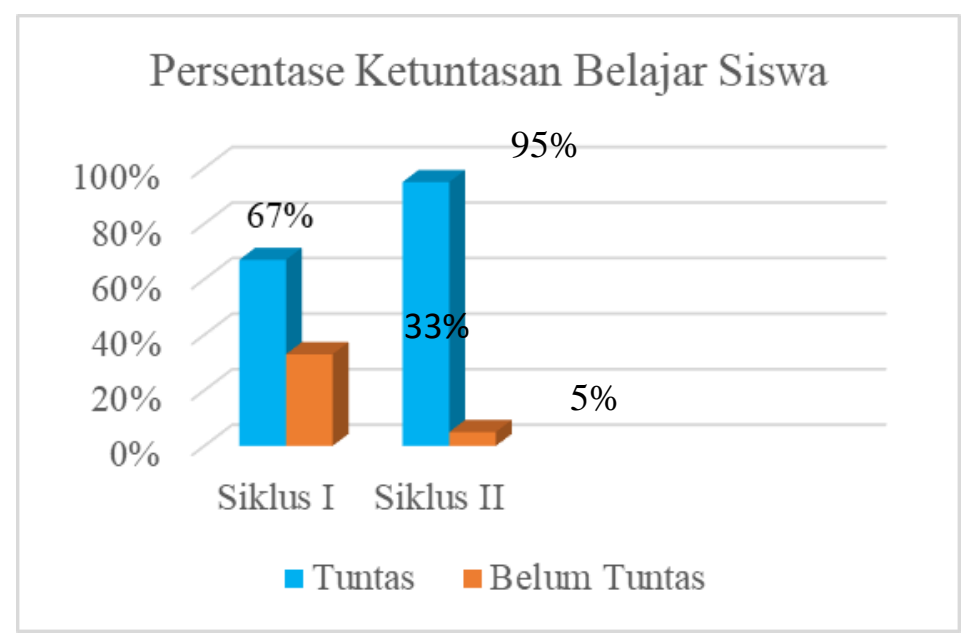

\section{Grafik 1. Peningkatan Hasil Belajar Siswa}

Berdasarkan hasil penelitian, pada siklus I hasil belajar yang diperoleh siswa masih kurang dari kriteria keberhasilan yang telah ditetapkan (70\%). Hal ini dikarenakan terdapat indikator dalam pembelajaran yang masih dirasa sulit oleh siswa yaitu menjumlahkan bilangan bulat negatif dengan bilangan bulat negatif. Pada siklus II hasil belajar siswa sesuai dengan kriteria yang telah ditetapkan dan hasil hasil belajar siswa termasuk dalam kategori "Sangat Baik".

\section{Pembahasan Hasil Penelitian}

1. Perencanaan Pembelajaran

Peneliti membuat RPP sesuai silabus mata pelajaran matematika sebelum melaksanakan penelitian, dengan kompetensi dasar 5.2 menjumlahkan bilangan bulat menggunakan model pembelajaran NHT. Peneliti melaksanakan penelitian 2 siklus, dimana setiap siklus dilengkapi dengan Rencana Pelaksanaan Pembelajaran (RPP), Lembar Kerja Siswa (LKS), Lembar Soal Pre Test dan Post Test, Lembar 
Observasi (Instrumen Penilaian). Penilaian terhadap RPP digunakan lembar observasi instrumen penilaian RPP.

Berdasarkan hasil observasi dalam perencanaan pembelajaran (RPP), peneliti harus dapat memenuhi beberapa aspek perencanaan pembelajaran yang telah ditentukan dalam lembar observasi. Hal ini dimaksudkan untuk melihat seberapa jauh peneliti telah mencapai aspek-aspek perencanaan yang telah ditentukan dalam melaksanakan tindakan pembelajaran pada setiap siklus. Terdapat tujuh aspek yang diamati, setiap aspek memiliki empat indikator dengan jumlah total seluruh indikator 28. Aspek-aspek yang diamati diantaranya; Aspek Standar Kompetensi, Kompetensi Dasar, dan Indikator Pencapaian Kompetensi; Perumusan dan Penetapan Tujuan Pembelajaran; Pengembangan Materi Pembelajaran; Penetapan Metode Pembelajaran; Pengembangan Langkah-langkah Pembelajaran; Penggunaan Alat, Media dan Sumber Pembelajaran; Evaluasi. Skor yang diberian observer kepada peneliti dalam pemenuhan setiap aspek yaitu; skor 1 = kurang; 2 = cukup; 3 = baik; 4 = sangat baik. Observasi rencana pelaksanaan pembelajaran ini dilakukan oleh observer melalui lembar observasi instrumen penilaian RPP.

Hasil penilaian RPP dari setiap siklus mengalami peningkatan. Data hasil observasi Rencana Pelaksanaan Pembelajaran pada siklus I, penilaian RPP dapat dikatakan "Baik" dengan persentase yang didapat yaitu 86,60\% dan rata-rata 3,46. Siklus II mengalami peningkatan dengan kategori "Sangat Baik" dan persentase yang diperoleh yaitu $96,42 \%$ dengan rata-rata 3,85 . Hal ini dikarenakan seluruh indikator telah terpenuhi dengan baik, indikator pelaksanaan evaluasi telah sesuai dengan alokasi pembelajaran yang telah ditentukan. Berdasarkan data peningkatan, dapat disimpulkan bahwa terdapat peningkatan dalam merancang perencanaan pembelajaran pada materi operasi penjumlahan bilangan bulat dengan menggunakan model pembelajaran $\mathrm{NHT}$, dengan nilai akhir persentasenya tidak kurang dari $70 \%$.

\section{Pelaksanaan Pembelajaran}

Pelaksanaan pembelajaran pada setiap siklus dilaksanakan sesuai perencanaan pembelajaran yang telah direncanakan sebelumnya. Kegiatan pembelajaran dilaksanakan melalui kegiatan awal, kegiatan inti dan kegiatan akhir dengan menggunakan model NHT. Proses pelaksanaan pembelajaran dinilai dengan menggunakan instrumen penilaian kinerja guru. Melalui lembar observasi kinerja guru, dapat dilihat bagaimana peneliti melaksanakan pembelajaran dengan menggunakan model pembelajaran NHT pada operasi penjumlahan bilangan bulat. Terdapat tujuh aspek yang diamati, setiap aspek memiliki empat indikator dengan jumlah total seluruh indikator 28. Aspek-aspek yang diamati diantaranya; Kemampuan Guru Membuka Pembelajaran; Kemampuan Guru dalam Penguasaan Bahan Ajar; Kemampuan Mengajar Guru dalam Penggunaan Model NHT; Proses Pembelajaran Guru; Kemampuan Menggunakan Media Pembelajaran; Evaluasi; Kemapuan Guru Menutup Pembelajaran.

Berdasarkan hasil observasi proses pelaksanaan pembelajaran pada siklus I, penilaian kinerja guru dapat dikatakan "Baik" dengan persentase yang didapat yaitu $88,39 \%$ dan rata-rata 3,53 . Siklus II mengalami peningkatan dengan kategori "Sangat Baik" dan persentase yang diperoleh yaitu 97,32\% dengan rata-rata 3,89. Indikator pelaksanaan evaluasi sesuai dengan alokasi waktu yang telah ditentukan. Peneliti mampu memotivasi siswa untuk menyimak presentasi di depan kelas 
sehingga siswa pandai mengajukan pendapat atau komentar dalam menanggapi hasil diskusi kelompok.

Melihat data hasil observasi, dapat disimpulkan bahwa terdapat peningkatan dalam proses pelaksanaan pembelajaran pada setiap siklus. Pelaksanaan pembelajaran dengan menggunakan model pembelajaran NHT pada operasi penjumlahan bilangan bulat di kelas IV, memberikan dampak positif adanya perubahan lebih baik dalam proses pembelajaran yaitu: siswa dapat berpikir bersama untuk memecahkan masalah, terlibat aktif dalam pembelajaran dan dapat memberikan kesempatan pada siswa untuk saling membagikan ide-ide dan mempertimbangkan jawaban yang paling tepat sehingga hal tersebut dapat menunjang terhadap pencapaian hasil belajarnya. Sebagaimana yang dikatakan oleh Trianto (2010) "NHT atau penomoran berpikir bersama merupakan jenis pembelajaran kooperatif yang dirancang untuk mempengaruhi pola interaksi siswa dan sebagai alternatif terhadap struktur kelas tradisional."

Pada saat proses pembelajaran berlangsung, peneliti mengamati aktivitas siswa dalam mengikuti kegiatan pembelajaran dengan menggunakan model pembelajaran NHT secara menyeluruh dengan bantuan observer. Terdapat sepuluh indikator yang diamati, dengan skor total yang harus tepenuhi yaitu 40 dan rata-rata yang diperoleh maksimal 4 dengan maksimal persentase yang diperoleh yaitu $100 \%$. Aktivitas siswa selama proses pembelajaran berdasarkan hasil penelitian menunjukkan bahwa, dengan menggunakan model pembelajaran NHT pada materi operasi penjumlahan bilangan bulat pada setiap siklus aktivitas siswa mengalami peningkatan. Hasil perolehan data mengenai aktivitas siwa dalam proses pembelajaran menggunakan model pembelajaran NHT, maka dapat dilihat data yang diperoleh dari siklus I aktivitas siswa dikatakan "Cukup" dengan pesentase $77,5 \%$ dan rata-rata yang diperoleh yaitu 3,1 . Pada siklus II, aktivitas siswa mengalami peningkatan termasuk pada kategori "Sangat baik" dengan persentase $95 \%$ dan rata-rata yang diperoleh yaitu 3,8 .

Penggunaan model NHT membuat siswa lebih aktif dalam proses pembelajaran, dapat meningkatkan rasa ingin tahu siswa, karena setiap indikator terutama indikator dalam menyimak presentasi dan mengajukan pendapat meningkat dari siklus I ke siklus II sehingga hasil belajar siswa dapat meningkat. Hal ini sesuai dengan pendapat Kurniasih dan Berlin, S (2015) "Kelebihan model NHT antara lain; a) Dapat meningkatkan prestasi belajar siswa; b) mampu memperdalam pemahaman siswa; c) melatih tanggung jawab siswa; d) menyenangkan siswa dalam belajar; e) mengembangkan rasa ingin tahu; f) meningkatkan rasa percaya diri siswa; g) setiap siswa termotivasi untuk menguasai materi." Maka dari itu, aktivitas siswa dalam proses pembelajaran dengan menggunakan model pembelajaran NHT menjadi lebih baik dari sebelumnya.

\section{Hasil Belajar Siswa}

Hasil belajar siswa pada proses pembelajaran dengan menggunakan model pembelajaran $\mathrm{NHT}$, dapat diperoleh dari hasil penilaian secara individu dengan mengerjakan soal-soal post test tentang materi operasi penjumlahan bilangan bulat setelah proses pembelajaran berlangsung. Hasil belajar siswa dari dua siklus mengalami peningkatan. Hal ini dapat dilihat pada tabel 4 pada hasil penelitian. Berdasarkan data yang diperoleh pada siklus I dan II, hasil evaluasi skor post test siswa mengalami peningkatan. Pada siklus I hasil post test siswa mencapai rata- 
rata 72,38 dan persentase ketuntasan belajar $67 \%$. Sedangkan pada siklus II, skor rata-rata 90,48 dan persentase sebesar $95 \%$. Melihat dari data hasil penelitian yang dilakukan pada pembelajaran siklus I dan II, siswa mengalami peningkatan hasil belajar setelah melewati proses pembelajaran dengan menggunakan model pembelajaran NHT. Hal ini dibandingkan dengan hasil pre test yang dilakukan oleh peneliti sebelum digunakannya model pembelajaran NHT pada operasi penjumlahan bilangan bulat, hanya 6 orang siswa atau 29\% dari 21 orang siswa yang tuntas KKM dengan rata-rata yang diperoleh hanya 53,33 dan hasil post test dari setiap siklus meningkat setelah digunakannya model NHT. Peningkatan skor rata-rata hasil belajar siswa dari siklus I ke siklus II sebesar18,1 poin. Wahyuddin (2017) "Model pembelajaran NHT adalah salah satu tipe pembelajaran kooperatif yang menekankan pada struktur khusus yang dirancang untuk mempengaruhi pola interaksi siswa dan memiliki tujuan untuk meningkatkan penguasaan akademik." Siswa mengalami perubahan suasana dalam pembelajarannya di kelas yang dapat berpengaruh terhadap hasil belajar yang diperolehnya. Hal ini sesuai dengan apa yang telah diungkapkan oleh Sudjana, Nana (2016) "Proses belajar adalah penunjang hasil belajar yang ingin dicapai siswa."

Penggunaan model Pembelajaran NHT mampu meningkatkan hasil belajar siswa. Beberapa penelitian mengenai penggunaan model pembelajaran NHT telah banyak dilakukan oleh peneliti terdahulu. (Maryam,2015; Pratiwi,2018; Suryati dan Syarfuni,2014) menemukan bahwa "penerapan model pembelajaran kooperatif tipe NHT dalam pembelajaran matematika dapat meningkatkan hasil belajar siswa." Berdasarkan hasil penelitian yang dilakukan oleh peneliti, relevan dengan penelitian yang dilakukan oleh peneliti terdahulu. Hasil penelitian menunjukkan bahwa pembelajaran matematika pada operasi penjumlahan bilangan bulat dengan menggunakan model pembelajaran Numbered Head Together dapat meningkatkan hasil belajar siswa di Kelas IV SDN Sindangheula Kecamatan Cibalong Kabupaten Tasikmalaya Tahun Ajaran 2018/2019.

\section{SIMPULAN}

1. Berdasarkan hasil penelitian dan pembahasan yang telah diuraikan, terbukti bahwa pembelajaran matematika pada operasi penjumlahan bilangan bulat dengan menggunakan model pembelajaran NHT dapat meningkatkan hasil belajar siswa Kelas IV SDN Sindangheula Kecamatan Cibalong Kabupaten Tasikmalaya Tahun Ajaran 2018/2019. Peningkatan hasil belajar siswa ditinjau dari:

2. Perencanaan pembelajaran matematika pada operasi penjumlahan bilangan bulat dengan menggunakan model NHT mengalami peningkatan, dengan kategori yang didapat sangat baik. Peneliti sudah mampu membuat perencanaan pembelajaran sesuai dengan indikator pembelajaran yang ditetapkan.

3. Pelaksanaan pembelajaran matematika pada operasi penjumlahan bilangan bulat dengan menggunakan model pembelajaran NHT di Kelas IV SDN Sindangheula mengalami peningkatan dengan kategori yang didapat sangat baik. Hal ini dikarenakan seluruh indikator telah terpenuhi dengan baik.

4. Hasil analis menunjukkan bahwa, hasil pre test ketuntasan belajar siswa hanya mencapai persentase 29\% (6 orang siswa) dan yang belum tuntas KKM 71\% (15 orang siwa) dengan rata-rata skor 53,33 . Setelah dilakukannya tindakan penelitian dengan menggunakan model pembelajaran NHT hasil belajar siswa meningkat pada setiap siklus. Siklus I ketuntasan belajar siswa mencapai persentase sebesar $67 \%$ (14 orang siswa) dan yang belum tuntas KKM 33\% (7 orang siswa) dengan rata-rata skor yang diperoleh 72,38 . Siklus II mencapai persentase 95\% (20 orang 
siswa) tuntas belajar, dan hanya $5 \%$ (1 orang siswa) belum tuntas KKM dengan rata-rata kelas yang diperoleh 90,48. Peningkatan rata-rata skor hasil belajar siswa sebesar 18,1 poin.

\section{DAFTAR PUSTAKA}

Alfiyah, S. (2012). Penerapan model pembelajaran cooperative NHT (Numbered Heads Together) dalam Meningkatkan Prestasi Belajar Siswa Pada Pokok Bahasan Bilangan Romawi Mata Pelajaran Matematika Kelas IV SD (Penelitian Tindakan Kelas di SDN 1 Karangwangun Kecamatan Babakan Kabupaten Cirebon).(Doctoral dissertation, IAIN Syekh Nurjati Cirebon).

Dewi, F. (2016). Pengaruh Model Pembelajaran Kooperatif Tipe Numbered Head Together Terhadap Hasil Belajar Siswa Pada Mata Pelajaran Matematika Kelas V SDN 1 Raman Endra tahun pelajaran 2015/2016. Bandar Lampung. UNILA.

Haryati, N. (2015). Hubungan Minat Belajar Dengan Prestasi Belajar Matematika Siswa Kelas V Sd Se-Gugus Wonokerto Turi Sleman Tahun Ajaran 2014/2015. BASIC EDUCATION, 4 (13).

Hasibuan, N. (2014). Mengoptimalkan Hasil Belajar Melalui Pembelajaran Remedial. Edukasia: Jurnal Penelitian Pendidikan Islam, 9 (2).

Herman, T. dkk. (2010). Pendidikan Matematika I. Bandung: UPI PRESS.

Kurniasih dan Berlin, S. (2015). Ragam Pengembangan Model Pebelajaran. Yogyakarta: Kata Pena.

Maryam. (2015). Penerapan Pembelajaran Kooperatif tipe Numbered Head Together untuk Meningkatkan Hasil Belajar Siswa Pada Mata Pelajaran Matematika di Kelas IV SDN 21 Parepare. (Skripsi Program Studi Pendidikan Guru Sekolah Dasar FKIP Universitas Negeri Makasar). Makasar.

Mujiani, D. (2016). Pengaruh media pembelajaran dan kecerdasan logis matematis terhadap hasil belajar matematika siswa. Jurnal Pendidikan Dasar UNJ, 7 (2):199-209.

Pratiwi, D. (2018). Peningkatan Hasil Belajar Matematika Melalui Model Pembelajaran Kooperatif Tipe NHT di SDN Nomporejo. Jurnal Pendidikan Guru Sekolah Dasar, $11(7): 56$.

Rusman. (2016). Model-Model Pembelajaran. Jakarta: PT Rajagrafindo Persada.

Sidik, G. S., \& Wakih, A. A. (2019). Kesulitan Belajar Matematik Siswa Sekolah Dasar Pada Operasi Hitung Bilangan Bulat. Naturalistic: Jurnal Kajian Penelitian Pendidikan dan Pembelajaran, 4(1), 461-470.

Sudjana, Nana. (2016). Penilaian Hasil Proses Belajar Mengajar. Bandung: Rosdakarya.

Suryati dan Syarfuni. (2014). Penerapan Model Pembelajaran Kooperatif Tipe NHT untuk Meningkatkan Hasil Belajar Matematika Keliling dan Luas Jajar Genjang di Kelas IV SDN 32 Banda Aceh. Jurnal Tunas Bangsa, 4 (2):83.

Trianto. (2010). Model-Model Pembelajaran Inovatif Berorientasi Konstruktivistik. Jakarta: Prestasi Pustaka.

Wahyuddin. (2017). Penerapan Pembelajaran NHT pada Siswa Kelas V SD Negeri 75 Ujungpero Kecamatan Sabbangparu Kabupaten Wajo Suska Journal of Mathematics Education, 3 (1):58. 